\title{
Employee Perceptions of the Effectiveness of E- training to Meet Performance Evaluation Requirements
}

\author{
Areej M. Altwijri ${ }^{*}$ \\ Prince Sattam Bin Abdulaziz University, Alkharj, Saudi Arabia \\ Tahani I. Aldosemani \\ Prince Sattam Bin Abdulaziz University, Alkharj, Saudi Arabia
}

\begin{abstract}
Saudi universities have moved to e-training programmes, including 'Ithrai' and other platforms, due to their potential effectiveness and cost-efficiency. However, limited efforts have been made to evaluate the effectiveness of e-training programmes in the context of university workplaces in Saudi Arabia using Job Performance Evaluation Charter JPEC. The purpose of this study is to address this gap in the literature by examining the effect of e-training on meeting JPEC requirements for employees in the public university context in Saudi Arabia. This study highlights that e-training approaches are important to ensure that employees have acquired essential competencies and skills using JPEC as the foundation for their evaluation. In addition, it is important to take into account the different levels of knowledge among employees and encourage cooperation in order to overcome the various knowledge gaps among them as a result of their different abilities in dealing with technology. Participants highly agreed on the impact of e-training in terms of meeting the requirements for evaluating job performance in the area of employee professional development with a mean of (4.19). This research, however, is subject to several limitations. First, the study occurred at one Saudi university and is geographically limited. It also relied on a small sample size and it may not be possible to generalise the reported perceptions to the whole institution or Saudi Arabia as a whole. Other researchers could replicate the study by including different institutions in different geographical regions. Second, all the data were self-reported and may suffer from social desirability bias. Thus, readers should interpret the findings with caution.
\end{abstract}

Keywords: E-training; university workplace; performance evaluation; university employees

\footnotetext{
*Corresponding author: Altwijri,Areej a.altwijri@psau.edu.sa
} 


\section{Introduction}

Training is one of the most important strategies for higher education institutions and universities in order to allow them to bridge the gap between job market requirements and work force capabilities, increase productivity, and improve the work environment. Professional staff training is planned primarily in order to upskill, reskill, and equip employees with the most necessary skills and knowledge to improve their performance and enhance their work attitudes throughout their professional path. As a result, the role of human resources management has moved from the traditional role of employee management processes like recruiting, promoting, and motivating staff to the strategic dimension of empowering individuals to achieve their full potential. Professional development training improves staff capabilities and qualifications. Employees in many professional fields are required to enrol in continuous training to maintain their professional qualifications and to enable them to respond to modern workplace demands. Human resources administrators tend to invest in training and focus on specific training needs (Tikhonov, 2020, p. 183). Human resources administrators adopt e-training for a range of reasons; these can include creating a unique training experience, taking advantage of the outcomes of globalisation and digital transformation, in addition to overcoming the problems and challenges associated with traditional training.

During the past decade, there has been great interest in the development of employee training processes to support the constant changes in the business environment. The importance of this research stems from the fact that universities need to develop their administrative processes through the leverage of technological tools and resources. Universities aim to exploit knowledge openness in developing e-training programmes and solutions. In adopting an etraining culture, universities develop employees, enabling them to perform the required tasks to reach their full potential. In more recent times, technological advancements have influenced training approaches and modalities within public institutions. Internet technologies and e-learning applications have led to fundamental improvements in the way institutions manage employees' training. E-training continues to grow in popularity and adoption as institutions enhance their competitiveness through the continuous development of a lifelong learning culture. Equally, institutions are increasingly improving their capabilities to respond to the immediate and strategic need for an agile and competent workforce. E-training is necessary for employees to ensure the acquisition of the necessary skills associated with job requirements and in order to reduce skills mismatch. This increases the need to adapt technology infrastructure to meet etraining requirements.

E-training requires careful management and planning, based on performance needs assessment, and it also needs to be aligned with university development requirements. Whenever training moves towards electronic solutions, this increases the demands to leverage Information and Communication Technology (ICT) infrastructure to support access, interaction, and the effective use of training opportunities among trainees (Kattuah \& Odeh, 2017). 
Saudi universities have moved to e-training programmes due to their potential effectiveness and cost-efficiency. However, only limited efforts have been made to evaluate their effectiveness in the context of university workplaces in Saudi Arabia. There is a gap in the literature that points to the need to examine the effect of e-training in meeting job performance evaluations (JPECs) (Guidelines for Job Performance Management Regulations, 2021) for employees in public universities in Saudi Arabia through e-training.

\section{Literature Review}

\section{E-training}

E-training is defined as the utilisation of electronic media for education and training activities in order to improve the skills and performance of training participants (Siswanto et al., 2018). It is training that is offered electronically in order to exchange knowledge by employing communication technologies via voice, image, or both (Al Mashagbh, Din et al., 2019; Durmaz et al., 2018). Etraining materials are combined with opportunities for open discussion and participation, utilising the trainee data to achieve the desired objectives and goals of training.

In recent years, internet use has greatly affected the culture of training in many universities, especially in the field of human resources' training. This has significantly contributed to the growing importance of e-training and its predominance over in-person training. A growing number of institutions are turning to electronic methods and practices in order to offer training in the workplace. Training is important for the professional development of human resources and can an institution to achieve its goals. Prior experiences have shown that the human factor is an essential and flexible component of high institutional productivity. Training contributes to its efficacy by enhancing employees' skills to meet various needs for workplace development (Al-Hila et al., 2017). Universities are now capable of providing learning and training environments that enhance employees' knowledge, skills, and attitudes (Yusuf \& Hasnidar, 2020). This has been made possible, in part, by exploiting multimedia and digital resources which can be used and reused in different learning and training environments (Barragán-Sánchez et al., 2018). E-training and learning are effective means of achieving better training outcomes. They can have an effect beyond training for specific job situations and can become an essential component of employees' professional growth (Satiman \& Boonlue, 2020).

Computer and internet-based training can include a myriad of electronic hardware and software solutions, facilitated by an instructor or through selfpaced modalities, whether synchronised, asynchronised, or mixed (Sirkemaa \& Varpelaide, 2018). Synchronised e-training models tend to follow the traditional training method by virtually gathering trainees to meet at specific times to share and exchange information and directly interact with other trainees. In addition, training is planned to enable trainees to develop a shared knowledge and to collaboratively construct a shared understanding of workplace concepts and the relationships between the different workplace concepts. Additionally, self-paced training programmes can be provided and enhanced using multiple channels and modalities, such as virtual training classes, teleconferencing, online chat forums, 
and live broadcasting (Bonfield et al., 2020). These can offer instant feedback and be implemented for different training purposes (Kattuah \& Odeh, 2017; Oproescu et al., 2019).

A growing number of universities and higher education institutions are using advanced training methods to upskill and reskill their employees; this includes adopting blended training methods, which can be defined as the use of a combination of direct and face-to-face online modalities for training purposes. An integrated approach to training allows staff to use self-paced training methods in combination with direct collaborative learning. This blended training approach can provide the employee with the dual benefits of both approaches and ensure that training services can be accessed by all employees. Moreover, e-training provides the opportunity to access training data and exploit participation and interactivity data to improve training plans and provide personalised training programmes (Golitsyna et al., 2019).

\section{The Job Performance Evaluation Charter (JPEC) in Saudi Arabia}

The Job Performance Evaluation Charter (JPEC) in Saudi Arabia is an evaluation checklist that has been approved by the Ministry of Civil Service, as part of the new 21-article job performance evaluation regulations that came into effect in 2018 (JPEC Guide, 2018). The JPEC must be completed annually by employees at public institutions and governmental entities to determine that they have fulfilled their self-identified goals, according to the required job competencies. The list items have relative weight and a targeted output for each goal, to be prepared by the employer, signed by the employee, and finally authorised by the entity's general human resources director at the beginning of each annual performance evaluation cycle. The goals represent the results the employees are expected to achieve during the performance evaluation term. Each employee must determine their own work goals and these must be specific, viable, logical, and particular to a certain timeframe. Competencies include the knowledge, skills, abilities, and behavioural characteristics that enable employees to perform their jobs effectively.

\section{E-training for Skills Development in the University Workplace}

The demand for e-training has grown dramatically in recent years, as a result of advancements in information and communication technology (ICT). E-training can bridge the gap between traditional training and workplace skill requirements (Al-Hila et al., 2017; Satiman \& Boonlue, 2020; Zainab et al., 2017). Employee training plays a vital role in improving job performance, as well as increasing productivity. It leads to the overall development of higher education institutions, helps to maintain competitive standards, and meet demands for human resources. There is a substantial difference between university workplaces that train their employees and those that do not provide such opportunities. E-training has a positive impact on employee skills and performance that is ultimately reflected in institutional performance.

Through e-training, universities can identify skill mismatches in relation to the required knowledge, skills and attitudes demanded by the workplace. However, universities need to implement ongoing policies for the training and retention of employees. Goals should not be planned solely to identify gaps in skills and 
performance (Quratul-Ain Talpur et al., 2017). The success of the workplace depends heavily on the productivity, skills, and capabilities of the workforce. Indeed, targeted training may be considered one of the best investments in the relationship between workplaces and employees. Indeed, a technology-mediated learning environment, combining online course content focused on professionalism with online collaboration-based programmes, enhances selfdirected learning skills, generating remarkable educational and professional benefits such as entrepreneurial skills, computer skills, and better performance (Nizhenkovska et al., 2020).

Subramaniam and Nakkeeran (2019) discussed the impact of corporate e-training systems on enhancing the performance of employees in software development companies. A pilot study was performed on primary data collected from 202 software specialists across different software organisations in India. Multiple linear regression analysis was applied to the data. The results revealed that the successful implementation and use of e-learning systems in software enterprises for employee training enhances team performance regardless of the geographical distance between trainees. Gavril et al. (2017) evaluated the impact of e-learning on the performance of employees and the performance of business organisations through globalised training opportunities. The study indicated how globalisation has led to a change in training and learning methods. High-quality training systems are implemented based on specific standards; therefore, it is necessary to consider the differences in the knowledge sets of employees in different countries and to develop compatible training systems. The study indicated knowledge gaps among staff members, based on internationally collected data and empirical research conducted in Romania. Besides statistical data, the researcher interviewed employees in 18 multinational companies that operate some of their business activities in Romania. The results of the research showed that the implementation of an effective e-learning strategy reduced the financial cost by $40-60 \%$, and it enabled the learning process and standardised inputs and outcomes to be fully measured.

Monaco (2017) examined the role of technology-based education in improving employee performance. This study discussed how to enhance traditional training in organisations through the implementation of e-training. It provided several examples of successful e-training courses, including the design model. It also demonstrated the advantages provided by e-training for both employees and employers. Online-based learning resources make class sessions more interesting as well as enhancing student learning outcomes (Rahman et al., 2020).

Kamal et al. (2016) explored the impact of e-training on employee performance, undertaking a practical study on the Ministry of Education in the Kingdom of Bahrain. This study aimed to identify the effect of e-training on the performance of employees in the Ministry of Education in the Kingdom of Bahrain. The study highlighted the importance of developing employees' skills to obtain high-quality performance through effective training. The study indicated how organisations leverage advanced technologies over the internet to train employees more quickly and effectively. The research adopted descriptive and analytical approaches through statistical data to determine the effect of e-training on employee 
performance. The selected sample consisted of 194 employees working in the Ministry of Education. The research concluded that there is a positive and significant relationship between e-training and employee performance, with a correlation coefficient of 0.358 , and a regression coefficient demonstrating that the efficiency of e-training affected job performance by $25.3 \%$. The results also indicated that there are statistically significant differences in terms of demographic variables (such as an employee's qualifications and job experience). The study recommended that all employees should be enrolled in the e-training programmes provided by the Ministry of Education. The study demonstrated how the long-term success of the organisation was determined, in large part, by widely disseminating an e-training culture among employees for better performance results.

Sharma et al. (2016) explored the importance, role, and impact of e-training on employees in the workplace. The study examined the impact of ICT and the increasing use of web-based training to prepare skilled employees. The study indicated that most organisations should engage in e-training to avoid problems related to cost, performance, and benefits. The study also demonstrated how ICT has revolutionised the world through technological innovation to deliver training, helping to bridge the gap between organisational performance and employee performance. The researchers used both a qualitative and a quantitative approach to employee performance, examining the following objectives: training, user satisfaction, ongoing intent, and individual performance. Training was studied on multiple levels to measure digital literacy and expected performance. The results suggested that e-training had a substantial effect on improving employee competencies and skill development. Andriushchenko et al., (2020) findings revealed an increase in the input quantity and quality of the continuity of education through distance education learning as a means of ensuring a sustained and qualified workforce.

Digital literacy has a positive impact on the professional environment as it enhances communication and problem-solving skills among employees; it describes digitisation models for changing professional development programmes and plans that are continuous, social, personalised and focused on the needs and interests of the individual (Andriushchenko et al., 2020).

This study sheds light on the effect of e-training in meeting the requirements of performance evaluation and how it equips and empowers employees with the competencies required for JPEC. It focuses on employees' perspectives. The following questions guided this study:

1. What are employees' perceptions of the impact of e-training on improving performance evaluation (specifically in terms of enhancing employees' sense of responsibility, cooperation skills, communication skills, accomplishments, self-development, and professional engagement) in university work environments?

2. What are employees' perceptions of the most important factors in e-training that support job performance evaluation (specifically in enhancing employees' sense of responsibility, cooperation skills, communication skills, 
accomplishments, self-development, and professional engagement) in university work environments?

3. What are employees' perceptions of the main challenges in e-training that could hinder job performance evaluation (in terms of sense of responsibility, cooperation, communication, accomplishment, employee development, and job engagement) in university work environments?

4. Is there an effect of e-training based on academic qualification, number of years of employment service, number of electronic training courses obtained)?

\section{The Significance of the Study}

The importance of this research stems from the need for universities to develop their administrative processes through the leverage of technological tools and resources. Universities aim to exploit open educational resources in developing etraining programmes and solutions. In disseminating an e-training culture, universities develop employees, enabling them to perform the tasks necessary to reach their full potential. There is a growing need to measure the impact of etraining in meeting the requirements to evaluate the job performance of employees in universities. There is also a need to enrich national resources with recommendations from national human resources' development leaders' perspectives. The results of this study will support university stakeholders in the development of policies for implementing e-training and enhancing the skills, capabilities, and competencies of employees. Moreover, this study will support the identification of the strengths and weaknesses of e-training systems and improve training quality, as well as employee skill levels. Finally, it will contribute to the advancement of training modalities at the university level to meet job performance evaluation.

\section{Methodology}

\section{Study Context}

Governmental sectors in Saudi Arabia are witnessing administrative challenges in terms of evaluating employees' performance given the requirement to apply new evaluation regulations to measure job performance. These challenges, affecting many governmental department managers and directors, range from the difficulty of interpreting regulation policies to the lack of understanding of the best strategies to implement these regulations. For the past two years, the Ministry of Civil Services and other government agencies have held numerous workshops to raise awareness of the new set of regulations among employees and administrators and to disseminate information about it. Stakeholders have not been confident about the proper application of these new regulations, especially since administrators are required to apply new systems for employee evaluation. The administrators' lack of knowledge of the new regulations has exacerbated this challenge.

As a result, a royal decree was issued to launch the King Salman Programme for Human Resource Development (KSPHRD). Its objectives are: to raise the quality of human resources performance, to develop all the policies and procedures necessary for the application of the new programme, and to enhance the work environment within governmental institutions in the Kingdom. The establishment of KSPHRD coincided with the new JPEC, a performance charter 
for employees, listing the required skills and performance commitments to be agreed upon by the employee. The Ministry of Civil Services began orientation workshops and training courses for KSPHRD. It worked in coordination with the Ministry of Social Affairs, directly after the issuance of the royal decree to launch the programme, authorising the Ministry of Civil Service to set up standards and mechanisms for the implementation of the programme. Training workshops focused on two new targeted departments for the programme: the Department of Management and Development, and the Department of Internal Communication. KSPHRD seeks to achieve a number of goals, including enhancing the quality of government employees' performance and their productivity at work; improving work environments; developing clear policies and procedures for implementing human resources' development plans; and preparing future leaders to build their capacities.

As part of its commitment to participation in the KSPHRD programme, the Institute of Public Administration launched the e-training platform 'Ithrai' ('Enrichment' in Arabic). This platform offers ten new e-training programmes, in multiple fields, for annual training of government employees. The 'Ithrai' platform is one of the first e-training platforms dedicated to government employees and its primary goal is to enhance employees' job performance and workforce productivity. The Ithrai training platform provides many training programmes in different specialties and disciplines through online conferences and webinars, in addition to Arabic-language enrichment content in various online formats. The platform has had more than four million visits. To date, the number of beneficiaries has exceeded four million trainees from different governmental sectors and more than 100 thousand attendees for online conferences.

Saudi universities have moved to e-training programmes, including 'Ithrai' and other platforms, due to their potential effectiveness and cost-efficiency. However, only limited efforts have been made to evaluate the effectiveness of e-training programmes in the context of university workplaces in Saudi Arabia. The purpose of this study is to address this gap in the literature by examining the effect of etraining in meeting the JPEC among employees in public universities in Saudi Arabia. This quantitative study depicts employees' perceptions of the effectiveness of e-training in supporting the achievement of the JPEC requirements at one public university, as well as the benefits and challenges encountered during their e-training experience. Participants were employees working in administrative roles in an emerging public university in the central region of Saudi Arabia. Emerging universities in Saudi Arabia include 13 higher education institutions that have been established during the past 10 years to serve communities in regions distant from major metropolitan areas, decreasing pressure on the eight main universities. The university has 19 colleges (including two community colleges) on seven campuses interspersed throughout the central region of Saudi Arabia. The university employs more than 1,600 academic staff and has more than 26,000 students enrolled. 


\section{Participants}

The study sample consists of all 683 employees at a university in central Saudi Arabia. The stratified sampling of participants consisted of 230 employees. Several key demographic variables have been identified to describe the study sample, including academic qualification, years of work experience, and the number of e-training courses undertaken during employment at the university.

\section{Academic Qualifications}

Table 1 indicates that $67.0 \%$ of the participants (154) have a bachelor's degree, $17.4 \%(40)$ are educated to secondary level, 9.6\% (22) have a post-secondary diploma, 3.5\% (8) have a master's degree, and 2.6\% (6) have another academic or professional degree. In addition, $50.4 \%$ of the participants (116) have 5-10 years of work experience, $47.0 \%$ (108) have more than 10, and $2.6 \%$ (6) of participants have work experience of less than 5 years. Table 3 shows the distribution of the study sample according to the number of e-training courses undertaken during employment at the university; $73.9 \%$ of participants (170) undertook more than three courses, and $7.8 \%$ (18) of the total participants undertook only one course.

Table 1: Sample According to Academic Status and Professional Experience

\begin{tabular}{|l|c|c|}
\hline \multicolumn{1}{|c|}{ Academic Status } & Frequency & Percentage \\
\hline Intermediate & 6 & 2.6 \\
\hline High School & 40 & 17.4 \\
\hline Certificate & 22 & 9.6 \\
\hline Bachelor's & 154 & 67.0 \\
\hline Master's & 8 & 3.5 \\
& \multicolumn{2}{|l|}{} \\
\hline Professional Experience & \multicolumn{2}{|c|}{} \\
\hline Less than 5 years & 6 & 2.6 \\
\hline From 5-10 years & 116 & $\mathbf{1 0 0} \%$ \\
\hline Total & $\mathbf{2 3 0}$ & \\
\hline
\end{tabular}

Table 2: Number of E-training Courses Undertaken during Employment at the University

\begin{tabular}{|l|c|c|}
\hline \multicolumn{1}{|c|}{ Number of E-training courses } & Frequency & Percentage \\
\hline One course & 18 & 7.8 \\
\hline Two courses & 12 & 5.2 \\
\hline Three courses & 30 & 13.0 \\
\hline More than three courses & 170 & 73.9 \\
\hline \multicolumn{1}{|c|}{ Total } & $\mathbf{2 3 0}$ & $\mathbf{1 0 0} \%$ \\
\hline
\end{tabular}

\section{Instrument}

The descriptive analytical method of this study examines a real phenomenon through accurate descriptions, expressed qualitatively and quantitatively. It consists of collecting coded data and information about the phenomenon or problem, classifying, analysing, and subjecting it to research. The data collection instrument was developed based on the JPEC form. The guidelines for the job performance list include six competencies and 21 statements. To verify the validity and reliability of the questionnaire, two methods were used. First, seven 
faculty members with human resources, professional development, and etraining expertise were recruited to review the clarity of the questionnaire statements, their relatedness to the main statements, and their relevance. Reviewers were also consulted to suggest any required amendments and changes. Necessary amendments were made based on agreement between the majority of reviewers until the questionnaire reached its final form.

Second, to ensure the validity of the internal consistency of the tool, a Pearson correlation coefficient was calculated to identify the degree of correlation of each questionnaire item with the total score of the statements (see Table 4). The correlation coefficient values for each of the statements with the main statements are positive, and statistically significant at the chosen significance level of (0.01) or less. This indicates the credibility of the internal consistency between the questionnaire statements, and their suitability for the purposes of the study. Additionally, the stability of the study instrument was confirmed using Cronbach's Alpha (a) stability coefficient. Tables 3-8 give the values for the Cronbach's stability coefficients for each dimension. Cronbach's alpha coefficient is generally high (0.936).

Table 4: Correlation of E-training Effectiveness Factors

\begin{tabular}{|l|l|l|l|l|}
\hline Statement & $\begin{array}{l}\text { Statement } \\
\text { Number }\end{array}$ & Correlation & Number & Correlation \\
\hline \multirow{2}{*}{ Sense of Responsibility } & 1 & $* * 0.794$ & 3 & $* * 0.781$ \\
\cline { 2 - 5 } & 2 & $* * 0.886$ & - & - \\
\hline \multirow{2}{*}{ Cooperation } & 4 & $* * 0.719$ & 6 & $* * 0.832$ \\
\cline { 2 - 5 } & 5 & $* * 0.667$ & 7 & $* * 0.813$ \\
\hline \multirow{2}{*}{ Communication } & 8 & $* * 0.826$ & 10 & $* * 0.787$ \\
\cline { 2 - 5 } & 9 & $* * 0.884$ & - & - \\
\hline \multirow{3}{*}{ Accomplishment } & 11 & $* * 0.753$ & 14 & $* * 0.783$ \\
\cline { 2 - 5 } & 12 & $* * 0.843$ & 15 & $* * 0.753$ \\
\cline { 2 - 5 } & 13 & $* * 0.718$ & - & - \\
\hline \multirow{2}{*}{$\begin{array}{l}\text { Professional } \\
\text { Development }\end{array}$} & 16 & $* * 0.877$ & 17 & $* * 0.912$ \\
\hline Engagement & 18 & $* * 0.850$ & 20 & $* * 0.753$ \\
\cline { 2 - 5 } & 19 & $* * 0.877$ & 21 & $* * 0.778$ \\
\hline
\end{tabular}

Table 5: Cronbach Alpha to Measure Stability of Statements in Study Instrument

\begin{tabular}{|c|c|c|c|}
\hline Questionnaire & Statement & Number & Stability \\
\hline \multirow{6}{*}{$\begin{array}{l}\text { E-training effectiveness in improving } \\
\text { employee evaluation requirements (Sense } \\
\text { of Responsibility, Cooperation, } \\
\text { Communication, Accomplishment, } \\
\text { Professional Development, Engagement) }\end{array}$} & $\begin{array}{l}\text { Sense of } \\
\text { Responsibility }\end{array}$ & 3 & 0.753 \\
\hline & Cooperation & 4 & 0.752 \\
\hline & Communication & 3 & 0.777 \\
\hline & Accomplishment & 5 & 0.821 \\
\hline & $\begin{array}{l}\text { Professional } \\
\text { Development }\end{array}$ & 2 & 0.746 \\
\hline & Engagement & 4 & 0.831 \\
\hline \multicolumn{2}{|l|}{ General Stability } & 21 & 0.936 \\
\hline
\end{tabular}




\section{Data Collection}

Ethics approval and permission for this study were obtained from the Deanship of Research. Data were collected using a questionnaire distributed to all the employees in 14 different colleges via e-mail invitations in March 2021. One reminder was sent three weeks after the initial request. The study sample consisted of 230 participants and the questionnaire was distributed electronically via university email. Data collection was completed in May 2021. A five-point Likert scale was used to collect responses according to the following degrees of approval: very likely - likely - neutral - unlikely - very unlikely, and with means and standard deviations for each statement (4.21-5.00 very likely, 3.41-4.20 likely, 2.613.40 neutral, 1.81-2.60 very unlikely, 1.00 -1.80 unlikely)

\section{Data Analysis}

Statistical Packages for Social Sciences (SPSS) analysis was undertaken and the following statistical measures were calculated: 1) frequencies and percentages to identify the characteristics of the study sample and determine the responses to the main statement items; 2) means and standard deviation to determine the participant responses to the study statements; 3) Kolmogorov-Smirnov to test and verify the normality of variables distribution; 4) Levene's test for homogeneity of variance; 5) Kruskal-Wallis test to verify the direction of differences within the sample; 6) Scheffe test to verify the direction of the differences within the study sample identified by the Kruskal-Wallis Test.

\section{Results}

The first question was as follows: What is the impact of e-training on meeting the job performance evaluation requirements (regarding Sense of Responsibility, Cooperation, Communication, Accomplishment, Staff Development, and Job Engagement) among employees in university workplaces? The means of these dimensions were calculated (see Table 6). The results demonstrated that the participants agreed, to a high degree, on the impact of e-training in terms of meeting the requirements for job performance evaluation. At an average of (4.18), this item ranked in the highest degree of agreement. For the dimension of Accomplishment, there was an average of (4.26) agreement; for Engagement, an average of (4.24), followed by the Communication dimension. See the table below for detailed results.

Table 6: Means and Standard Deviations for Participants' Perceptions of the Impact of E-training on Meeting the Requirements for the Job Performance Evaluation

\begin{tabular}{|l|l|l|l|}
\hline Statement & Rank & SD & M \\
\hline Sense of Responsibility & 5 & 0.594 & 4.14 \\
\hline Cooperation & 6 & 0.600 & 4.00 \\
\hline Communication & 3 & 0.606 & 4.23 \\
\hline Accomplishment & 1 & 0.546 & 4.26 \\
\hline Professional Development & 4 & 0.710 & 4.19 \\
\hline Engagement infectiveness in improving employee & - & 0.571 & 4.24 \\
\hline $\begin{array}{l}\text { E-training effech } \\
\text { evaluation requirements }\end{array}$ & 2 & 0.490 \\
\hline
\end{tabular}




\section{Sense of Responsibility}

The means and standard deviations were calculated for the Sense of Responsibility dimension (see Table 7). Participants highly agreed on the impact of e-training in terms of meeting the requirements for the job performance evaluation, with regard to the dimension of the Sense of Responsibility, with an average of (4.14). The statement "I understand my role and its connection to the institution" received a mean of (4.23) and a high degree of agreement. The statement "I report whatever I am facing with transparency" ranked last, with a mean of (4.00).

Table 7: Means and Standard Deviations for the Sense of Responsibility Dimension

\begin{tabular}{|l|l|l|l|}
\hline & Statement & $\mathbf{M}$ & SD \\
\hline 2 & $\begin{array}{l}\text { I understand my role and how it is linked to the general } \\
\text { university goals. }\end{array}$ & 4.23 & 0.691 \\
\hline 1 & $\begin{array}{l}\text { I take responsibility for my acts and decisions and do not } \\
\text { blame others. }\end{array}$ & 4.17 & 0.727 \\
\hline 3 & I report whatever I am facing with transparency. & 4 & 0.759 \\
\hline Average & 4.14 & 0.594 \\
\hline
\end{tabular}

\section{Cooperation}

Means and standard deviations for the Cooperation dimension were calculated. The participants agreed, to a high degree, on the impact of e-training on meeting the requirements for the job performance evaluation with regard to the Cooperation dimension, with a mean of (4.00). The statement "I seek to benefit from the opinions of others from outside my administration" was ranked first, with a mean of (4.10) and a high degree of approval. The statement "I engage others in supporting my work by initiating supportive relationships with them" ranked last, with a mean of (3.82) and a high degree of approval.

Table 8: Means and Standard Deviations for the Cooperation Dimension

\begin{tabular}{|l|l|l|l|}
\hline & Statement & M & SD \\
\hline 5 & $\begin{array}{l}\text { I seek to benefit from the opinions of others } \\
\text { from outside my administration }\end{array}$ & 4.10 & 0.759 \\
\hline 7 & $\begin{array}{l}\text { I respond to support and assistance requests } \\
\text { from the university's organisational units. }\end{array}$ & 4.08 & 0.726 \\
\hline 4 & $\begin{array}{l}\text { I openly share information according to the } \\
\text { job requirements. }\end{array}$ & 4 & 0.825 \\
\hline 6 & $\begin{array}{l}\text { I engage others in supporting my work by } \\
\text { initiating supportive relationships with them }\end{array}$ & 3.82 & 0.852 \\
\hline Average & 4 & 0.6 \\
\hline
\end{tabular}

\section{Communication}

Means and standard deviations of the Communication dimension were calculated (see Table 9). Participants agreed, to a high degree, on the impact of e-training in terms of meeting the requirements for the job performance evaluation with regard to the Communication dimension, with an average of (4.23). The statement "I 
carefully listen to others" ranked first, with a mean of (4.42) and a high degree of agreement. The statement "I use clear and effective written communication" ranked last, with a mean of (4.10).

Table 9: Means and Standard Deviations for the Communication Dimension

\begin{tabular}{|l|l|l|l|}
\hline & Statement & M SD & . \\
\hline 10 & I listen carefully to others. & 4.42 & 0.647 \\
\hline 9 & $\begin{array}{l}\text { I use clear and effective oral } \\
\text { communication. }\end{array}$ & 4.17 & 0.762 \\
\hline 8 & $\begin{array}{l}\text { I use clear and effective written } \\
\text { communication. }\end{array}$ & 4.10 & 0.77 \\
\hline Average & 4.23 & 0.606 \\
\hline
\end{tabular}

\section{Accomplishment}

Means and standard deviations for the Accomplishment dimension were calculated to examine the most important factor according to participants' perceptions (see Table 10). Participants agreed, to a high degree, on the impact of e-training in terms of meeting the requirements for the job performance evaluation, with regard to the dimension of Accomplishment, with an average of (4.26). The statement "I carry out my tasks on time with a high level of quality" ranked with a mean of (4.34) and a high degree of approval. The statement "I define the tasks and their priorities according to their relative importance" came last, with a mean of (4.22).

Table 10: Means and Standard Deviations for the Accomplishment Dimension

\begin{tabular}{|l|l|l|l|}
\hline Number & Statement & M & SD \\
\hline 14 & $\begin{array}{l}\text { I carry out my tasks on time with high } \\
\text { level of quality. }\end{array}$ & 4.34 & 0.604 \\
\hline 11 & I am a multi-tasker. & 4.26 & 0.737 \\
\hline 15 & $\begin{array}{l}\text { I take the initiative and work without a } \\
\text { request or directions from my manager. }\end{array}$ & 4.24 & 0.743 \\
\hline 13 & $\begin{array}{l}\text { My manager relies on me. } \\
\text { according to their importance. }\end{array}$ & 4.23 & 0.805 \\
\hline 12 & $\begin{array}{ll}\text { define } \\
\text { Average }\end{array}$ & 4.22 & 0.671 \\
\hline
\end{tabular}

\section{Employee Professional Development}

Means and standard deviations for the Employee Professional Development dimension were calculated (see Table 11). Participants highly agreed on the impact of e-training in terms of meeting the requirements for evaluating job performance, with regard to the dimension of Employee Professional Development, with a mean of (4.19). 
Table 11: Means and Standard Deviations for the Employee Professional Development Dimension

\begin{tabular}{|l|l|l|l|}
\hline & Statement & M & SD \\
\hline 16 & $\begin{array}{l}\text { I always work on educating } \\
\text { and improving myself. }\end{array}$ & 4.32 & 0.73 \\
\hline 17 & $\begin{array}{l}\text { I always participate in other } \\
\text { improvement opportunities for } \\
\text { my colleagues. }\end{array}$ & 4.05 & 0.855 \\
\hline \multicolumn{2}{|l|}{ Average } & 4.19 & 0.71 \\
\hline
\end{tabular}

\section{Engagement}

Means and standard deviations for the Engagement dimension were calculated (see Table 12). Participants highly agreed on the impact of e-training in terms of meeting the requirements of the job performance evaluation, with regard to the dimension of Engagement, with a mean of (4.24). The statement "I am committed to working hours and I am always available whenever needed" ranked highest, with a mean of (4.34). The statement "I am motivated to reach the optimal achievement level and creativity as I perform my tasks" ranked lowest, with a mean of (4.17).

Table 12: Means and Standard Deviations for the Engagement Dimension

\begin{tabular}{|l|l|l|l|}
\hline & Statement & M & SD \\
\hline 20 & $\begin{array}{l}\text { I am committed to working hours and I am always } \\
\text { available whenever needed. }\end{array}$ & 4.34 & 0.685 \\
\hline 21 & I focus on my clients while doing my job. & 4.26 & 0.607 \\
\hline 18 & I raise my preparedness to deal with work challenges. & 4.18 & 0.743 \\
\hline 19 & $\begin{array}{l}\text { I am motivated to reach the optimal achievement level and } \\
\text { creativity while performing my tasks. }\end{array}$ & 4.17 & 0.758 \\
Average & 4.24 & 5.71 \\
\hline
\end{tabular}

The second research question was as follows: What are the most important dimensions in the JPEC that e-training supports (including Sense of Responsibility, Cooperation, Communication, Accomplishment, Staff Professional Development, and Engagement) among employees at the institution?

The frequencies of questionnaire items were calculated for the most important dimensions that could be supported by e-training (see Table 13). Employees' Professional Development ranked highest, with a frequency number of (83), followed by Accomplishments (58), and Motivation had the lowest frequency at (4). Clearly the most important dimension that can be supported by e-training to meet the requirements for job performance evaluation is Staff Professional Development. 
Table 13: The Frequencies of Questionnaire Items for the Most Important Dimensions

\begin{tabular}{|l|l|l|}
\hline Factors & F & Rank \\
\hline Engagement & 21 & 6 \\
\hline Cooperation & 44 & 4 \\
\hline Accomplishment & 58 & 2 \\
\hline Employees' Professional Development & 83 & 1 \\
\hline Sense of Responsibility & 45 & 3 \\
\hline Communication & 34 & 5 \\
\hline Motivation & 4 & 7 \\
\hline
\end{tabular}

The third question was: What are the challenges facing e-training in university workplaces?

The main challenges in the context of e-training, hindering the job performance evaluation requirements for employees, are the lack of cooperation, with a frequency of (51), followed by lack of sense of engagement, with a frequency of (46). The least reported item (2) was the lack of staff professional development hindering employees from performing tasks (see Table 14).

Table 14: Frequencies and Ranks of Reported Challenges Related to E-training

\begin{tabular}{|l|l|l|}
\hline Challenges & Frequency & Rank \\
\hline Lack of engagement & 46 & 2 \\
\hline Communication issues & 23 & 5 \\
\hline Lack of sense of accomplishment & 6 & 6 \\
\hline $\begin{array}{l}\text { Lack of employees' professional self- } \\
\text { development opportunities }\end{array}$ & 2 & 8 \\
\hline $\begin{array}{l}\text { Lack of employee promotion opportunities } \\
\text { Lack of institutional professional } \\
\text { development opportunities }\end{array}$ & 45 & 7 \\
\hline Lack of cooperation & 51 & 3 \\
\hline Lack of sense of responsibility & 33 & 4 \\
\hline
\end{tabular}

The fourth research question was: Are there any statistically significant differences, at the level of significance (> 0.05), for the effectiveness of e-training in terms of meeting the JPEC, for demographic variables (qualification, job Title, years of experience, number of E-training courses)?

To determine the validity of the differences between the qualification categories, the Scheffe test was used (see Table 15). There are statistically significant differences at the level of (0.05) and less between those with bachelor's and master's degrees, for Sense of Responsibility, with a high degree for participants with master's degrees. There are statistically significant differences at the level of $(0.05)$ and less between those with bachelor's and master's degrees for 
Accomplishment, with a higher degree for participants whose qualifications are bachelor's or master's degrees. There are statistically significant differences at the level of (0.05) and less between those with master's degrees in Staff Professional Development items, with a higher degree for participants with master's degrees. There are statistically significant differences at the level of (0.05) and less between those with bachelor's degrees, regarding Organisational Affiliation, with higher degree for participants with bachelor's degrees. There are statistically significant differences at the level of (0.01) and less between those with master's degrees, regarding Engagement, with higher degree for participants with master's degrees. There are statistically significant differences at the level of (0.05) and less for job performance evaluation requirements, with a higher degree for participants with master's degrees.

Table 15: Differences According to Qualification Categories

\begin{tabular}{|c|c|c|c|c|c|c|c|c|}
\hline Statement & Qualification & $\mathbf{N}$ & $\mathbf{M}$ & 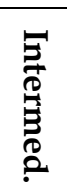 & 昰 & - & 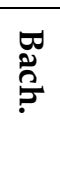 & 3 \\
\hline \multirow[t]{5}{*}{ Sense of Responsibility } & Intermediate & 6 & 4.33 & - & & & & \\
\hline & $\begin{array}{ll}\begin{array}{l}\text { High } \\
\text { (HS) }\end{array} & \\
\end{array}$ & 40 & 4.12 & & - & & & \\
\hline & Diploma & 22 & 4.27 & & & - & & \\
\hline & Bachelor's & 154 & 4.08 & & & & - & $*$ \\
\hline & Master's & 8 & 4.75 & & & & & - \\
\hline \multirow{5}{*}{ Accomplishment } & Intermediate & 6 & 4.53 & - & & & & \\
\hline & High School & 40 & 4 & & - & & $*$ & $*$ \\
\hline & Diploma & 22 & 4.18 & & & - & & \\
\hline & Bachelor's & 154 & 4.3 & & & & - & \\
\hline & Master's & 8 & 4.7 & & & & & - \\
\hline \multirow[t]{5}{*}{ Professional Development } & Intermediate & 6 & 4.5 & - & & & & \\
\hline & High School & 40 & 3.9 & & - & & & $*$ \\
\hline & Diploma & 22 & 3.91 & & & - & & \\
\hline & Bachelor's & 154 & 4.26 & & & & - & \\
\hline & Master's & 8 & 4.75 & & & & & - \\
\hline \multirow[t]{5}{*}{ Engagement } & Intermediate & 6 & 4.5 & - & & & & \\
\hline & High School & 40 & 3.94 & & - & & $*$ & $* *$ \\
\hline & Diploma & 22 & 4.18 & & & - & & \\
\hline & Bachelor's & 154 & 4.29 & & & & - & \\
\hline & Master's & 8 & 4.75 & & & & & - \\
\hline \multirow{5}{*}{$\begin{array}{ll}\text { Performance } & \text { Evaluation } \\
\text { Requirements } & \end{array}$} & Intermediate & 6 & 4.46 & - & & & & \\
\hline & High School & 40 & 4 & & - & & & $*$ \\
\hline & Diploma & 22 & 4.17 & & & - & & \\
\hline & Bachelor's & 154 & 4.19 & & & & - & \\
\hline & Master's & 8 & 4.63 & & & & & - \\
\hline
\end{tabular}

To determine the validity of the differences between the categories for the number of years of employment, the Scheffe test was used (see Table 17). There are statistically significant differences at the level of (0.01) and less between participants with years of employment ranging from 5-10 years and those with 
more than 10 years, regarding Sense of Responsibility, with a higher level for participants with the number of years of work experience at more than 10 years. There are statistically significant differences at the level of $(0.01)$ and less between participants whose number of years of experience is less than 5 years in Staff Professional Development, with a higher level for participants whose years of work experience ranges from 5 years and up. There are statistically significant differences at the level of (0.05) and less between participants with work experience from 5-10 years and more than 10 years, regarding Engagement, Job Performance, and Evaluation Requirements, with a higher level for participants whose number of years of work experience is 10 or more years.

Table 17: Differences Between the Categories for the Number of Years of Employment

\begin{tabular}{|c|c|c|c|c|c|c|c|}
\hline Statement & $\begin{array}{l}\text { Work } \\
\text { Experience } \\
\text { in Years }\end{array}$ & $\mathbf{N}$ & $\mathbf{M}$ & $\begin{array}{l}\text { Less } \\
\text { than } \\
5 \\
\end{array}$ & $\begin{array}{l}\text { From } \\
5-10\end{array}$ & $\begin{array}{l}\text { More } \\
\text { than } \\
10 \\
\end{array}$ & $\begin{array}{c}\text { Statistical } \\
\text { significance }\end{array}$ \\
\hline \multirow{3}{*}{$\begin{array}{l}\text { Sense of } \\
\text { Responsibility }\end{array}$} & Less than 5 & 6 & 4.11 & - & & & 0.200 \\
\hline & From 5-10 & 116 & 4.02 & & - & $* *$ & ***0.000 \\
\hline & More than 5 & 108 & 4.27 & & & - & ***0.000 \\
\hline \multirow{3}{*}{$\begin{array}{l}\text { Professional } \\
\text { Development }\end{array}$} & Less than 5 & 6 & 3 & - & $* *$ & $* *$ & ***0.002 \\
\hline & From 5-10 & 116 & 4.16 & & - & & ***0.000 \\
\hline & More than10 & 108 & 4.29 & & & - & ***0000 \\
\hline \multirow[t]{3}{*}{ Engagement } & Less than 5 & 6 & 4.25 & - & & & 0.200 \\
\hline & From 5-10 & 116 & 4.14 & & - & $*$ & ***0.000 \\
\hline & More than10 & 108 & 4.34 & & & - & ***0.000 \\
\hline \multirow{3}{*}{$\begin{array}{l}\text { Performance } \\
\text { Evaluation } \\
\text { Requirements }\end{array}$} & Less than 5 & 6 & 3.97 & - & & & **0.002 \\
\hline & From 5-10 & 116 & 4.11 & & - & $*$ & ***0.000 \\
\hline & More than10 & 108 & 4.26 & & & - & ***0.001 \\
\hline
\end{tabular}

A one-way analysis of variance was used to clarify the significance of the differences in the responses according to the variable identifying number of etraining courses undertaken (see Table 18). There are no statistically significant differences at the level of $(0.05)$ or less in the Communication category according to the variable for number of e-training courses undertaken. There are statistically significant differences at the level of $(0.01)$ and less for the requirements for evaluating job performance (Sense of Responsibility, Cooperation, Accomplishment, Staff Development, and Job Correlation) according to the variable for number of e-training courses undertaken. 
Table 18: Differences According to the Variable for Number of E-training Courses Undertaken

\begin{tabular}{|c|c|c|c|c|c|c|}
\hline Dimension & Variance & $\begin{array}{l}\text { Squire } \\
\text { sum }\end{array}$ & Freedom & SM & F & $\begin{array}{l}\text { Statistical } \\
\text { significance }\end{array}$ \\
\hline \multirow[t]{3}{*}{$\begin{array}{ll}\text { Sense } & \text { of } \\
\text { Responsibility } & \end{array}$} & $\begin{array}{l}\text { Between } \\
\text { groups }\end{array}$ & 5.909 & 3 & 1.97 & \multirow[t]{3}{*}{5.94} & \multirow[t]{3}{*}{$* * 0.001$} \\
\hline & $\begin{array}{l}\text { Within } \\
\text { groups }\end{array}$ & 74.934 & 226 & 0.332 & & \\
\hline & Sum & 80.843 & 229 & - & & \\
\hline \multirow[t]{3}{*}{ Cooperation } & $\begin{array}{l}\text { Between } \\
\text { groups }\end{array}$ & 8.514 & 3 & 2.838 & \multirow[t]{3}{*}{8.683} & \multirow[t]{3}{*}{$* * 0.000$} \\
\hline & $\begin{array}{l}\text { Within } \\
\text { groups }\end{array}$ & 73.86 & 226 & 0.327 & & \\
\hline & Sum & 82.374 & 229 & - & & \\
\hline \multirow[t]{3}{*}{ Communication } & $\begin{array}{l}\text { Between } \\
\text { groups }\end{array}$ & 2.689 & 3 & 0.896 & \multirow[t]{3}{*}{2.486} & \multirow[t]{3}{*}{0.061} \\
\hline & $\begin{array}{l}\text { Within } \\
\text { groups }\end{array}$ & 81.162 & 226 & 0.361 & & \\
\hline & Sum & 84.162 & 229 & - & & \\
\hline \multirow[t]{3}{*}{ Accomplishment } & $\begin{array}{l}\text { Between } \\
\text { groups }\end{array}$ & 8.28 & 3 & 2.76 & \multirow[t]{3}{*}{10.395} & \multirow[t]{3}{*}{$* * 0.000$} \\
\hline & $\begin{array}{l}\text { Within } \\
\text { groups }\end{array}$ & 60.003 & 226 & 0.265 & & \\
\hline & Sum & 68.282 & 229 & - & & \\
\hline \multirow[t]{3}{*}{$\begin{array}{l}\text { Professional } \\
\text { Development }\end{array}$} & $\begin{array}{l}\text { Between } \\
\text { groups }\end{array}$ & 15.495 & 3 & 5.165 & \multirow[t]{3}{*}{11.677} & \multirow[t]{3}{*}{$* * 0.000$} \\
\hline & $\begin{array}{l}\text { Within } \\
\text { groups }\end{array}$ & 99.966 & 226 & 0.442 & & \\
\hline & Sum & 115.461 & 229 & - & & \\
\hline \multirow[t]{3}{*}{ Engagement } & $\begin{array}{l}\text { Between } \\
\text { groups }\end{array}$ & 3.71 & 3 & 1.237 & \multirow[t]{3}{*}{3.936} & \multirow[t]{3}{*}{$* * 0.009$} \\
\hline & $\begin{array}{l}\text { Within } \\
\text { groups }\end{array}$ & 71.001 & 226 & 0.314 & & \\
\hline & Sum & 74.711 & 229 & - & & \\
\hline \multirow{3}{*}{$\begin{array}{l}\text { Performance } \\
\text { Evaluation } \\
\text { Requirements }\end{array}$} & $\begin{array}{l}\text { Between } \\
\text { groups }\end{array}$ & 6.313 & 3 & 2.104 & \multirow[t]{3}{*}{9.759} & \multirow[t]{3}{*}{$* * 0.000$} \\
\hline & $\begin{array}{l}\text { Within } \\
\text { groups }\end{array}$ & 48.727 & 226 & 0.216 & & \\
\hline & Sum & 55.04 & 229 & - & & \\
\hline
\end{tabular}

To determine the validity of the differences between the categories for the number of e-training courses undertaken, the Scheffe test was used (see Table 19). There are statistically significant differences at the level of (0.05) and less for Sense of Responsibility, in favour of participants who had undertaken more than three courses. In addition, there are statistically significant differences in the Cooperation category, at the level of (0.05) and less for the study sample of participants who had undertaken three courses or less and those who had undertaken more than three courses, with a higher degree for those who had undertaken more than three courses. In the Accomplishment category, there are statistically significant differences at the level of (0.01) and less, in favour of those who had undertaken more than three courses. In the Staff Development category, 
there are statistically significant differences at the level of (0.01) and less for those who had undertaken one course, three courses, and those who had undertaken more than three courses, in favour of those who had obtained more than three courses. In the Engagement category, there are statistically significant differences at the level of (0.01) and less for those who had undertaken two courses in comparison with those who had undertaken more than three courses, in favour of those with more than three courses.

Table 19: Validity of the Differences Between the Categories of the Number of Etraining Courses Received

\begin{tabular}{|c|c|c|c|c|c|c|c|c|}
\hline Statement & $\begin{array}{l}\text { Number } \\
\text { of } \\
\text { courses }\end{array}$ & 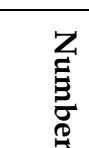 & 3 & 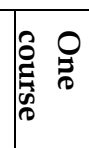 & 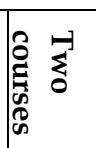 & 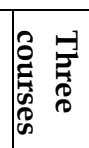 & $\begin{array}{l}\text { More } \\
\text { than } \\
\text { three }\end{array}$ & $\begin{array}{l}\text { Statistical } \\
\text { significance }\end{array}$ \\
\hline \multirow{4}{*}{$\begin{array}{l}\text { Sense of } \\
\text { Responsibility }\end{array}$} & 1 & 18 & 3.85 & - & & & & ${ }^{* *} 0.000$ \\
\hline & 2 & 12 & 3.89 & & - & & & 0.073 \\
\hline & 3 & 30 & 3.87 & & & - & $*$ & ${ }^{*} 0.028$ \\
\hline & $3+$ & 170 & 4.23 & & & & - & ${ }^{* *} 0.000$ \\
\hline \multirow[t]{4}{*}{ Cooperation } & 1 & 18 & 3.64 & - & & & * & ${ }^{* *} 0.001$ \\
\hline & 2 & 12 & 3.54 & & - & & $*$ & *0.023 \\
\hline & 3 & 30 & 3.77 & & & - & $*$ & ${ }^{* *} 0.001$ \\
\hline & $3+$ & 170 & 4.11 & & & & - & ${ }^{* *} 0.000$ \\
\hline \multirow[t]{4}{*}{ Accomplishment } & 2 & 18 & 3.8 & - & & & ** & ${ }^{* * *} 0.000$ \\
\hline & 2 & 12 & 3.83 & & - & & $* *$ & 0.196 \\
\hline & 3 & 30 & 4.12 & & & - & & *0.022 \\
\hline & $3+$ & 170 & 4.36 & & & & - & ${ }^{* *} 0.000$ \\
\hline \multirow{4}{*}{$\begin{array}{l}\text { Professional } \\
\text { Development }\end{array}$} & 1 & 18 & 3.56 & - & & & ** & ${ }^{* *} 0.001$ \\
\hline & 2 & 12 & 3.83 & & - & & & 0.200 \\
\hline & $3+$ & 30 & 3.87 & & & - & $* *$ & ${ }^{*} 0.019$ \\
\hline & $3+$ & 170 & 4.34 & & & & - & ${ }^{* *} 0.000$ \\
\hline \multirow[t]{4}{*}{ Engagement } & 1 & 18 & 4.03 & - & & & $*$ & ${ }^{* *} 0.001$ \\
\hline & 2 & 12 & 3.83 & & - & & $* *$ & 0.073 \\
\hline & 3 & 30 & 4.15 & & & - & & ${ }^{*} 0.041$ \\
\hline & $3+$ & 170 & 4.3 & & & & - & ${ }^{* *} 0.000$ \\
\hline \multirow{4}{*}{$\begin{array}{l}\text { Performance } \\
\text { Evaluation } \\
\text { Requirements }\end{array}$} & 1 & 18 & 3.83 & - & & & $* *$ & ${ }^{* * *} 0.000$ \\
\hline & 2 & 12 & 3.8 & & - & & $*$ & 0.145 \\
\hline & 3 & 30 & 4 & & & - & $*$ & ${ }^{* *} 0.000$ \\
\hline & $3+$ & 170 & 4.27 & & & & - & ${ }^{* * *} 0.000$ \\
\hline
\end{tabular}

In the category of Performance Evaluation Requirements, there are statistically significant differences at the level of $(0.05)$ and less for those who had undertaken two to three courses, compared with those who had undertaken more than three courses, with a higher degree for those with more than three courses. 


\section{Discussion}

Participants highly agreed on the impact of e-training in terms of meeting the requirements for the job performance evaluation. This aligns with Subramaniam and Nakkeeran (2019) who indicated that the successful implementation and use of e-learning systems in higher education institutions, for the purposes of employee training, enhances the performance of teams, despite any geographical distance between team members. Furthermore, it supports the development of a sense of responsibility among employees and the significant impact of e-training on the development of human resources.

Participants also agreed, to a high degree, on the impact of e-training in terms of meeting the requirements for the job performance evaluation with regard to the cooperation dimension. This aligns with Gavril et al. (2017), who asserted the importance of taking into account employees' different levels of knowledge. They affirmed the need to develop training systems that encourage cooperation among employees to overcome the different knowledge gaps among them as a result of their different abilities in terms of dealing with technology. With regard to cooperation among employees, e-training supports employees in terms of sharing and exchanging their expertise. Employee cooperation and collaboration between different departments facilitates the process of exchanging ideas and experiences by enabling the workforce to build supportive relationships with others. In addition, participants agreed, to a high degree, on the impact of e-training in terms of meeting the requirements for the job performance evaluation in relation to the communication dimension. This aligns with Sharma et al. (2016), who affirmed that ICT revolutionised training systems through technological innovation and eliminated communication challenges among the horizontal or vertical hierarchy of the organisation. ICT helps to bridge the gap between organisational goals and employee performance. These results also confirmed that e-training has a tangible impact on improving the organisational communication atmosphere and developing employees' communication skills.

This also highlights that communication is essential to the success of institutions and their departments, at all levels of management, to support the fulfillment of the institutional vision, mission, and goals.

Participants agreed, to a high degree, on the impact of e-training in terms of meeting the requirements for the job performance evaluation, with regard to the dimension of accomplishment. This aligns with Kamal et al. (2016), who emphasised that e-training significantly improves employee performance. The efficiency of e-training positively affects job performance by $25.3 \%$, ultimately increasing employees' work accomplishments. More importantly, participants highly agreed on the impact of e-training in terms of meeting the requirements for evaluating job performance, with regard to the dimension of employee professional development. The result of this study is consistent with Kamal et al. (2016) and Monaco (2017). E-training has noticeable positive outcomes on the performance and development of employees and a significant impact on the achievement of benefits for employees. Participants highly agreed on the impact of e-training in terms of meeting the requirements for the job performance evaluation, in relation to the dimension of engagement. 
This is consistent with the results of Gavril et al. (2017), Kamal et al. (2016), Subramaniam and Nakkeeran (2019), Monaco (2017) and Sharma et al. (2016). Etraining is an effective means of employee development to help overcome and bridge the gap between job goals and employee performance, as well as employees' sense of engagement in their workplace and motivation at work. In addition, the results of this study show statistically significant differences in terms of the demographic variables for qualification level and number of years of experience in terms of perceiving the benefits and impact of e-training, in line with the study by Kamal et al. (2016); they recommended that all employees should be involved in e-training programmes provided through institutional training courses and self-paced training opportunities to enhance knowledge exchange based on different expertise, previous experience, age, and other variables.

This research highlights the need to leverage technological tools and resources to upskill universities' employees. Universities can exploit ICT tools and knowledge openness in developing e-training programmes and solutions to support employees to reach their full potential. There is a growing need to measure the impact of e-training to fulfil the requirements to evaluate the job performance of employees in universities from the perspectives of stakeholders. University stakeholders should invest in the development of training modalities and policies that can support the implementation of e-training and enhance employees' skills, capabilities, and competence.

\section{Conclusion}

Training approaches are important to ensure that employees in higher education institutions acquire the necessary competencies and skills. Providing e-training opportunities enhances the spirit of cooperation among employees. Employees can also collaborate in training with peers, sharing their expertise and knowledge, and thereby training one another. In addition, employees can collaborate in terms of content creation for job evaluation competencies and e-training kits, enhancing their sense of responsibility. It is important to diversify e-training modalities and approaches to include self-learning and lifelong learning opportunities. This study also recommends the creation of integrated training programmes that extend over long training periods and include the necessary skills required to evaluate job performance and the accomplishment of work tasks. One area for future research involves the potential challenges that could impede effective etraining and hinder the ability to meet job performance evaluation requirements. It is also important to investigate how to design customised e-training programmes to meet the requirements for specific job performance evaluation, tailored to institutional and individual needs and goals. This research, however, is subject to several limitations. First, the study occurred at one Saudi university and is geographically limited. It also relied on a small sample size and it may not be possible to generalise the reported perceptions to the whole institution or Saudi Arabia as a whole. Other researchers may replicate the study by including different institutions in different geographical regions. Second, all the data were self-reported and may suffer from social desirability bias. Thus, readers should interpret the findings with caution. 


\section{References}

Al-Hila, A. A., Alhelou, E., Al Shobaki, M. J., \& Abu Naser, S. S. (2017). The impact of applying the dimensions of IT Governance in improving e-training-: Case study of the Ministry of Telecommunications and Information Technology in Gaza Governorates. International Journal of Engineering and Information Systems (IJEAIS), 1(7), 194-219. https:/ / hal.archives-ouvertes.fr/hal-01628897

Al Mashagbh, A., Din, R., Nasir, M. M. K, Halim, L., \& Al-Batainah, R. A. (2019). Reliability and Validity of Online Individualized Multimedia Instruction Instrument for Engineering Communication Skills. Creative Education, 10(12), 3041-3048. https:// doi.org /10.4236/ce.2019.1012228

Andriushchenko, K. \& Oleksandr, Rozhko \& Tepliuk, Mariia \& Iryna, Semenyshyna \& Evgen, Kartashov \& Anastasiia, Liezina. (2020). Digital Literacy Development Trends in the Professional Environment. International Journal of Learning, Teaching and Educational Research, 19, 55-79. http://doi.org/10.26803/ijlter.19.7.4.

Bari, M., Djouab, R., \& Hoa, C. P. (2018). Elearning current situation and emerging challenges. PEOPLE: International Journal of Social Sciences, 4(2), 97-109. https://dx.doi.org/10.20319/pijss.2018.42.97109

Barragán-Sánchez, R., Corujo-Vélez, M. C., Palacios-Rodríguez, A., \& Román-Graván, P. (2020). Teaching Digital Competence And Eco-Responsible Use Of Technologies: Development And Validation Of A Scale. Sustainability (Switzerland), 12(18). https://doi.org/10.3390/su12187721

Bonfield, C. A., Salter, M., Longmuir, A., Benson, M., \& Adachi, C. (2020). Transformation or Evolution?: Education 4.0, Teaching and Learning in the Digital Age. Higher Education Pedagogies, 5(1), 223-246. https:// doi.org/10.1080/23752696.2020.1816847

Durmaz, Y., Serin, E., \& Polat, H. (2018). Determination of problem-solving and communication skills of nursing/midwifery students. International Journal of Caring Sciences, 11(3), 1771-1777. http://www.internationaljournalofcaringsciences.org/docs/50_kaplanserin_ori ginal_11_3.pdf

Gavril, R. M., Kiehne, J., Hell, C. R., \& Kirschner, C. (2017). Impact assessment on the performance of e-learning in corporate training programs in the context of globalization. In Proceedings of the International Conference on Business Excellence, 11(1), 398-410. https:// doi.org/10.1515/picbe-2017-0043

Golitsyna, I. N., Eminov, F. I., \& Eminov, B. F. (2019). Education 4.0 in teaching/learning strategies. Proceedings - International Conference on Developments in ESystems Engineering, DeSE, October-20, 205-208. https://doi.org/10.25046/aj060254

Guidelines for Job Performance Management Regulations. (2021). Ministry of Human Resources Development. https://shortest.link/2INR

Kamal, K. B., Aghbari, M., \& Atteia, M. (2016). E-training \& employees' performance a practical study on the Ministry of Education in the Kingdom of Bahrain. Journal of Resources Development and Management, 18. https://www.iiste.org/Journals/index.php/JRDM/article/view/29346/30135

Kattuah, S., \& Odeh, K. (2017). E-training implementation in Saudi Arabia: An exploratory study in private sector in Jeddah. European Journal of Business and Management, $9(20), 30-36$.

Monaco, E. J. (2017). Using technology-assisted education to further employee development. The Educational Review, USA, 1(2), 26-33. http://dx.doi.org/10.26855/er.2017.02.002

Oproescu, M., Iana, G., Jianu, E., \& Anghel, M. R. (2019). E-learning in computer-assisted training, advantages, disadvantages, and future trends. In 2019 11th International 
Conference on Electronics, Computers and Artificial Intelligence (ECAI) (pp. 1-6). IEEE. https://doi.org/10.1109/ECAI46879.2019.9042063

Pham, P.-T., Tran, B. D., Phan, T.-T.-T., Nguyen, T.-H., Nguyen, M.-T. \& Tuyet, T. L. T., Nguyen, D. H., Yen, D. H., \& Nguyen, T.-T. (2020). Managing Continuing Education via Distance Learning and Face-to-Face Courses for Human Resource Development in the Mekong Delta of Vietnam. International Journal of Learning, Teaching and Educational Research, 19(10), 150-171. http://doi.org/10.26803/ijlter.19.10.9

Nizhenkovska, Iryna \& Reva, Tatyana \& Chkhalo, Oksana \& Holovchenko, Oksana. (2020). Technology-Driven Self-Directed Learning of Graduate Pharmaceutists: Adding Value through Entrepreneurship. International Journal of Learning, Teaching and Educational Research, 19, 111-126. http://doi.org/10.26803/ijlter.19.6.7

Quratul-Ain Talpur, A. J., Murtaza, G., Memon, Z. A., \& Bukhari, H. (2017). The relationship between employees' training and their performance in public universities in Pakistan. NICE Research Journal of Social Science, 9, 47-60. https://doi.org/10.51239/nrjss.v0i0.41

Rahman, A. B. A., Hussain, M. A. M., \& Zulkifli, R. M. (2020). Teaching vocational with technology: A study of teaching aids applied in Malaysian vocational classroom. International Journal of Learning, Teaching and Educational Research, 19(7), 176-188. https://doi.org/10.26803/ijlter.19.7.10

Satiman, A., \& Boonlue, S. (2020). The development of e-training system for government officers Bangkok metropolitan administration, Thailand. In Proceedings of the 2020 3 rd International Conference on Computers in Management and Business (pp. 180-183). ICCMB. https:/ / doi.org/ 10.1145/3383845.3383901

Sharma, S., Garg, S., \& Mittal, S. K. (2016). Importance, role and impact of e-training on employees in workplace. In V. Atal \& R. S. Dubey (Eds.), Proceedings of the 14th International Conference of the Society for Global Business \& Economic Development (SGBED) (pp. 474-485). Montclair State University.

Siswanto, Y., Sutarto, J., \& Mulyono, S. E. (2018). E-training based on determination of education and training models of early childhood teachers education programs. Journal of Nonformal Education, 4(2), 107-118. https://doi.org/10.15294/jne.v4i2.15517

Subramaniam, R., \& Nakkeeran, S. (2019). Impact of corporate e-learning systems in enhancing the team performance in virtual software teams. In A. Al-Masri \& K. Curran (Eds.), Smart technologies and innovation for a sustainable future (pp. 195204). Springer. https://doi.org/10.1007/978-3-030-01659-3_22

Tikhonov, A. (2020). Corporate training programs in Russian and foreign companies: Impact on staff and time challenges. International Journal of Higher Education, 9(3), 183-189. https://doi.org/10.5430/ijhe.v9n3p183

Yusuf, R. M., \& Hasnidar, H. (2020). Work-family conflict and career development on performance of married women employees. International Journal of Research in Business and Social Science (2147-4478), 9(1), 151-162. https://doi.org/10.20525/ijrbs.v9i1.601

Zainab, B., Awais Bhatti, M., \& Alshagawi, M. (2017). Factors affecting e-training adoption: An examination of perceived cost, computer self-efficacy and the technology acceptance model. Behaviour \& Information Technology, 36(12), 12611273. https://doi.org/10.1080/0144929X.2017.1380703 